\title{
PENGEMBANGAN PANDUAN PRAKTIKUM KIMIA DASAR TERINTEGRASI ETNOKIMIA UNTUK MAHASISWA
}

\author{
Henie Poerwandar Asmaningrum ${ }^{1 *}$, Imam Koirudin ${ }^{1}$ dan Kamariah $^{2}$ \\ ${ }^{1}$ Jurusan Pendidikan Kimia, FKIP, Universitas Musamus, Jalan Kamizaun Mopah Lama, \\ Merauke, 99611, Indonesia \\ ${ }^{2}$ Jurusan Pendidikan Matematika, FKIP, Universitas Musamus, Jalan Kamizaun Mopah Lama, \\ Merauke, 99611, Indonesia \\ *E-mail: poerwandar@unmus.ac.id
}

\begin{abstract}
ABSTRAK
Penelitian ini bertujuan untuk menghasilkan produk panduan praktikum kimia dasar terintegrasi etnokimia. Penelitian pengembangan dilakukan dalam tiga tahap, yaitu: 1) menganalisis materi (define), 2) mendesain prototype panduan (design), 3) validasi dan uji coba produk (develop). Validasi dilakukan oleh ahli materi dan ahli media. Uji coba dilakukan terhadap 17 mahasiswa untuk mengetahui respon dan keterampilan kerja ilmiah mahasiswa menggunakan panduan praktikum. Berdasarkan analisis data dapat diambil kesimpulan bahwa produk panduan praktikum dinyatakan valid oleh ahli materi (rerata 75\%) dan ahli media (rerata $86,25 \%$ ). Panduan dinyatakan layak digunakan, karena menunjukkan respon positif dan capaian keterampilan kinerja ilmiah mahasiwa yang sangat baik.
\end{abstract}

Kata kunci: pengembangan, panduan, praktikum, kimia dasar, etnokimia.

\begin{abstract}
This study aims to produce ethnochemistry-integrated basic chemistry experiment guide. The development research was carried out in three stages, i.e.: 1) analyzing the material (define), 2) designing the guide prototype (design), and 3 ) validation and product testing (develop). Validation was carried out by content experts and media experts. The experiment guide was tested to 17 students to find out the response and scientific work skills of students using the experiment guide. Based on data analysis, it can be concluded that the experiment guide produced was declared valid by the content expert (average 75\%) and media expert (average $86.25 \%$ ). The experiment guide is stated to be feasible for use, because it shows a positive response and the achievement of students' scientific performance skills is excellent.
\end{abstract}

Keywords: development, experiment guide, experiment, basic chemistry, ethnochemistry.

DOI: https://doi.org/10.15575/jtk.v3i2.3205 


\section{PENDAHULUAN}

Mata kuliah kimia dasar merupakan mata kuliah dasar untuk mempelajari ilmu kimia di tingkat universitas. Sebagian mahasiswa menganggap mata kuliah kimia merupakan mata kuliah yang sulit karena kimia bersifat abstrak (Chang, 2005). Agar konsep-konsep kimia dapat dipahami oleh mahasiswa maka pembelajaran kimia di universitas menekankan juga pada pemberian pengalaman belajar secara langsung melalui penggunaan dan pengembangan keterampilan proses dan sikap serta bisa memanfaatkan bahan yang ada di lingkungan sekitar yang mendukung pada proses pembelajaran. Dalam ilmu kimia terdapat dua hal yang sangat berkaitan dan tidak dapat dipisahkan, yaitu ilmu kimia sebagai produk (pengetahuan kimia berupa fakta, konsep, teori, dan prinsip) dan proses (kerja ilmiah) (BNSP, 2006). Kedua hal tersebut dapat dicapai peserta didik salah satunya melalui kegiatan praktikum.

Metode praktikum pada umumnya dirancang secara khusus agar mahasiswa dapat mengembangkan aktivitas belajar, memperoleh fakta dari konsep yang dipelajarinya, mengembangkan keterampilan dasar melakukan eksperimen, kemampuan memecahkan masalah dengan pendekatan ilmiah, meningkatkan pemahaman mengenai materi pelajaran, mengembangkan keterampilan dasar melakukan observasi, mengkomunikasikan hasil observasi secara lisan maupun tulisan dan dapat memfasilitasi rekonstruksi konsep-konsep atau membangun konsep sehingga dosen berperan dalam penguatan dan mengkoreksi konsep yang keliru (Murti dkk., 2014).

Panduan praktikum merupakan salah satu sarana yang diperlukan untuk memperlancar kegiatan belajar mengajar di laboratorium sehingga tujuan pembelajaran bisa tercapai dan memperkecil resiko kecelakaan. Panduan praktikum merupakan buku yang memuat topik praktikum, tujuan praktikum, dasar teori, alat dan bahan, prosedur praktikum, lembar hasil pengamataan serta soal-soal evaluasi yang dibuat berdasar tujuan praktikum.
Panduan praktikum merupakan fasilitas yang diberikan oleh dosen agar mahasiswa dapat belajar dan bekerja secara kontinu dan terarah. Pentingnya pengembangan panduan praktikum digunakan yaitu untuk mengaktifkan mahasiswa dan membantu mengembangkan keterampilan proses mahasiswa melalui kegiatan yang ada pada panduan praktikum yang telah dikembangkan (Prayitno, 2017).

Kekurangan atau tidak tersedianya berbagai bahan dan alat kimia seringkali menjadi kendala tidak berlangsungnya suatu topik praktikum. Menghadapi kendala seperti ini, sudah saatnya bagi guru, dosen dan siswa memikirkan jalan keluarnya. Seperti diketahui, bahwa "dunia ini adalah dunia kimia", artinya segala yang ada di dunia ini tidak terlepas dari aspek kimiawi. Hal ini memberikan inspirasi bahwa lingkungan sekitar sebenarnya merupakan sarana untuk belajar kimia dan untuk menunjukkan fenomena-fenomena kimiawi seperti yang tertulis dalam materi pelajaran kimia yang diajarkan di kelas.

Saat ini, kearifan lokal masih belum tergarap secara maksimal di tingkat perguruan tinggi. Program Studi Kimia maupun Pendidikan Kimia, masih jarang membekali lulusan dengan kompetensi unggulan berbasis kearifan lokal (Darmanto, 2009). Penyelenggaraan pendidikan kimia yang berbasis kearifan lokal akan memberikan ciri khas dan keunggulan lulusan. Selain itu juga akan menjadi ciri dan keunggulan institusi, dan pada akhirnya akan memberi kontribusi pada keunggulan bangsa.

Pengembangan aspek-aspek lokal menjadi kearifan lokal untuk menjadi keunggulan bangsa, jelas membutuhkan peran kimia. Penelitian mengenai kandungan, manfaat, pengembangan bahan alam jelas merupakan ranah keilmuan kimia. Perlu diupayakan penyelenggaraan pendidikan kimia yang berbasis kearifan lokal. Pendidikan sudah seharusnya memperhatikan local knowledge, local culture, local skills, dan local processes dalam membekali lulusannya. Sehingga ilmu dan keterampilan yang didapatkan menjadi kontekstual dengan jati diri dan berkelanjutan 
terus menerus. Kurikulumnya juga harus tertuju dan terkonsentrasi pada penyelesaian masalah bangsa (Darmanto, 2009).

Dalam mengembangkan kurikulum, perguruan tinggi harus mempertimbangkan societal needs, industrial needs, professional needs dan keunggulan bangsa atau kearifan lokal. Mata kuliah yang dirancang harus menyesuaikan dengan karakter lulusan yang dicita-citakan akan dihasilkan (Wimbarti, 2009). Kearifan lokal harus diidentifikasi oleh universitas untuk kemudian diberikan ke dalam proses pembelajaran. Integrasi kearifan lokal di dalam pendidikan kimia, juga bisa melalui materi ajar dan konsentrasi keilmuan atau mata kuliah pilihan (untuk tingkat pendidikan tinggi).

Pendidikan kimia berbasis kearifan lokal penting untuk diupayakan. Namun, sejauh ini pendidikan kimia berbasis kearifan lokal masih jarang dilakukan baik di tingkat sekolah menengah maupun perguruan tinggi. Pendidikan kimia yang tidak memperhatikan nilai dan potensi lokal, akan menghasilkan pendidikan yang tidak berorientasi pengembangan masyarakat (Merdekawati, 2012).

Merauke sebagai daerah yang terletak di Papua memiliki potensi budaya lokal yang sangat kaya. Kabupaten Merauke saja terdiri dari lebih dari 10 suku dengan budaya yang berdebeda-beda, contohnya Suku Marind, Suku Mapi, Suku Muyu, dan sebagainya. Hingga saat ini belum ada penelitian yang mengintegrasikan budaya-budaya masyarakat lokal Merauke ke dalam perangkat pembelajaran.

\section{METODE PENELITIAN}

Penelitian dilaksanakan pada semester genap Tahun Akademik 2016/2017 di Jurusan Pendidikan Kimia FKIP Universitas Musamus Merauke. Subjek penelitian ini adalah mahasiswa Jurusan Pendidikan Kimia yang mengambil mata kuliah praktikum kimia dasar, berjumlah 17 orang yang terdiri dari sepuluh perempuan dan tujuh laki-laki. Penelitan ini merupakan penelitian pengembangan. Model pengembangan yang digunakan adalah model 4-D Thiagarajan. Menurut Thiagarajan tahapan model pengembangan 4-D meliputi definisi, desain, pengembangan, dan penyebaran (Murdiani, 2012) yang dapat dilihat pada Gambar 1.

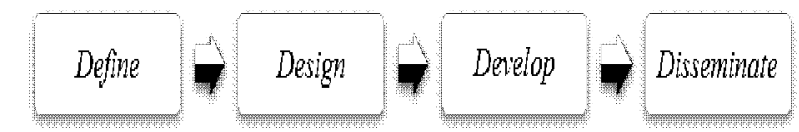

\section{Gambar 1. Model 4-D Thiagarajan}

Pada penelitian ini dilakukan hingga tahap develop. Berikut ini tahapan penelitian yang dilakukan: 1) Define: Tujuan dari kegiatan pada tahap ini adalah untuk menetapkan dan mendefinisikan syarat-syarat pengajaran (instructional). Melalui analisis ditentukan tujuan dan kendala untuk materi pengajaran (instruction materials). 2) Design: Tujuan dari kegiatan pada tahap ini adalah mendesain prototipe panduan praktikum kimia dasar. Kegiatan pada tahap ini dapat dilakukan setelah menentukan sekumpulan tujuan behavior (behavior objectives) untuk perangkat pembelajaran yang telah ditentukan. Pemilihan format dan media untuk bahan dan produksi versi awal mendasari aspek utama pada tahap desain. 3) Develop: pada tahap ini dilakukan validasi dan uji coba terbatas untuk mengetahui kelayakan prototipe panduan praktikum kimia dasar. Hasil uji validasi dan uji kelayakan digunakan untuk memperbaiki panduan produk.

Teknik pengumpulan data menggunakan instrumen lembar validasi ahli materi, lembar validasi media, lembar respon mahasiswa, dan rubrik penilaian keterampilan kerja ilmiah.

Penilaian kelayakan panduan praktikum kimia dasar dinilai oleh 2 (dua) orang ahli yang terdiri dari ahli materi dan ahli media. Indikator kelayakan ahli materi ditunjukkan pada Tabel 1. Adapun indikator kelayakan ahli media ditunjukkan pada Tabel 2.

Penilaian kelayakan panduan praktikum kimia dasar dinilai oleh mahasiswa dengan menggunakan angket respon. Indikator angket respon ditunjukkan pada Tabel 3. 
Tabel 1. Indikator Kelayakan Ahli Materi terhadap Panduan Praktikum Kimia Dasar

\begin{tabular}{|c|l|}
\hline No & \multicolumn{1}{|c|}{ Indikator } \\
\hline A. & Kebenaran konsep \\
\hline 1 & $\begin{array}{l}\text { Isi pedoman praktikum sesuai dengan materi } \\
\text { praktikum kimia }\end{array}$ \\
\hline 2 & $\begin{array}{l}\text { Penyajian praktikum sesuai dengan runtutan } \\
\text { materi praktikum yang diajarkan }\end{array}$ \\
\hline 3 & $\begin{array}{l}\text { Tata tertib praktikum sesuai dengan tata tertib } \\
\text { dalam laboratorium dan tertib pelaksanaan } \\
\text { praktikum praktikum berisi simbol-simbol }\end{array}$ \\
\hline 4 & $\begin{array}{l}\text { Pedoman pram } \\
\text { keselamatan kerja laboratorium }\end{array}$ \\
\hline 5 & $\begin{array}{l}\text { Kesesuaian tema praktikum dengan tujuan, } \\
\text { dasar teori, alat, bahan, cara kerja, dan teknik } \\
\text { analisis }\end{array}$ \\
\hline B. & Tingkat Keterlaksanaan Praktikum \\
\hline 6 & $\begin{array}{l}\text { Kegiatan yang dilakukan di panduan } \\
\text { praktikum tidak membahayakan }\end{array}$ \\
\hline 7 & $\begin{array}{l}\text { Praktikum mudah dilaksanakan dengan } \\
\text { ketersediaan bahan dan alat yang mudah } \\
\text { didapatkan }\end{array}$ \\
\hline 8 & $\begin{array}{l}\text { Kegiatan praktikum sesuai dengan alokasi } \\
\text { waktu panduan }\end{array}$ \\
\hline 9 & $\begin{array}{l}\text { Kegiatan praktikum dalam pan panduan } \\
\text { membentuk pengalaman langsung }\end{array}$ \\
\hline 10 & $\begin{array}{l}\text { Langkah kerja yang disajikan pada panduan } \\
\text { praktikum dilakukan secara runtut dan benar }\end{array}$ \\
\hline
\end{tabular}

Tabel 2. Indikator Kelayakan Ahli Media terhadap Panduan Praktikum Kimia Dasar

\begin{tabular}{|c|l|}
\hline \multicolumn{1}{|c|}{ No } & \multicolumn{1}{|c|}{ Indikator } \\
\hline A. Tampilan fisik \\
\hline 1 & $\begin{array}{l}\text { llustrasi sampul menggambarkan isi/materi } \\
\text { yang diajarkan }\end{array}$ \\
\hline 2 & $\begin{array}{l}\text { Desain sampul tidak terlalu banyak } \\
\text { menggunakan jenis huruf sehingga mudah } \\
\text { dibaca }\end{array}$ \\
\hline 3 & $\begin{array}{l}\text { Ukuran huruf pada sampul lebih dominan } \\
\text { dan proporsional dibandingkan nama } \\
\text { pengarang }\end{array}$ \\
\hline 4 & $\begin{array}{l}\text { Penampilan fisik panduan praktikum menarik } \\
\text { Sesuai dengan format yang dipilih disajikan }\end{array}$ \\
\hline B. & Kebahasaan \\
\hline 6 & $\begin{array}{l}\text { Bahasa yang digunakan dalam panduan } \\
\text { praktikum komunikatif dan interaktif }\end{array}$ \\
\hline 7 & $\begin{array}{l}\text { Bahasa dalam panduan praktikum sesuai } \\
\text { dengan perkembangan emosional mahasiswa }\end{array}$ \\
\hline 8 & $\begin{array}{l}\text { Pemilihan kata yang digunakan untuk } \\
\text { menyusun kalimat tidak menimbulkan makna } \\
\text { ambigu }\end{array}$ \\
\hline 9 & $\begin{array}{l}\text { Bahasa yang digunakan mudah dipahami dan } \\
\text { jelas }\end{array}$ \\
\hline 10 & Ketepatan ejaan dalam penulisan kalimat \\
\hline
\end{tabular}

Tabel 3. Indikator Respon Mahasiswa terhadap Panduan Praktikum Kimia Dasar

\begin{tabular}{|c|l|}
\hline No & \multicolumn{1}{|c|}{ Indikator } \\
\hline 1 & $\begin{array}{l}\text { Saya dapat menggunakan pedoman } \\
\text { praktikum ini sebagai sumber belajar untuk } \\
\text { pelaksanaan praktikum }\end{array}$ \\
\hline 2 & $\begin{array}{l}\text { Setelah menggunakan pedoman praktikum } \\
\text { ini, saya mendapat kemudahan dalam } \\
\text { memahami materi praktikum yang } \\
\text { diajarkan }\end{array}$ \\
\hline 3 & $\begin{array}{l}\text { Pedoman praktikum membantu saya dalam } \\
\text { membuat rumusan masalah dari materi } \\
\text { praktikum yang diajarkan }\end{array}$ \\
\hline 4 & $\begin{array}{l}\text { Saya dapat membuat hipotesis sebelum } \\
\text { praktikum dengan menggunakan pedoman } \\
\text { praktikum }\end{array}$ \\
\hline 5 & $\begin{array}{l}\text { Langkah-langkah percobaan yang ada } \\
\text { dalam pedoman praktikum dapat saya } \\
\text { pahami dengan baik }\end{array}$ \\
\hline 6 & $\begin{array}{l}\text { Saya melakukan praktikum kimia dasar } \\
\text { sesuai dengan petunjuk pada pedoman } \\
\text { praktikum }\end{array}$ \\
\hline 7 & $\begin{array}{l}\text { Hampir tidak ada kesulitan pada saat saya } \\
\text { melakukan praktikum } \\
\text { menggunakan pedoman tersebut }\end{array}$ \\
\hline 8 & $\begin{array}{l}\text { Setelah melakukan praktikum, saya } \\
\text { mendapatkan hasil pengamatan sesuai } \\
\text { dengan langkah percobaan }\end{array}$ \\
\hline 9 & $\begin{array}{l}\text { Hasil pengamatan yang saya lakukan dapat } \\
\text { dianalisis }\end{array}$ \\
\hline 10 & $\begin{array}{l}\text { Hipotesis yang saya buat dengan hasil } \\
\text { analisis saya sesuai dan benar }\end{array}$ \\
\hline 11 & $\begin{array}{l}\text { Hipotesis yang sesuai membantu saya } \\
\text { dalam menarik kesimpulan yang saya } \\
\text { lakukan merasa terbantu dalam melakukan }\end{array}$ \\
\hline 12 & $\begin{array}{l}\text { Saya manam jika ada pedoman praktikum } \\
\text { praktikum jika } \\
\text { tersebut }\end{array}$ \\
\hline
\end{tabular}

Skor mentah yang diperoleh diubah ke dalam bentuk persentase. Selanjutnya hasil persentase yang diperoleh dikonversi dalam kriteria kelayakan (Murdiani, 2012) berdasar pada Tabel 4.

Tabel 4. Kriteria Kelayakan Panduan Praktikum

\begin{tabular}{|c|c|}
\hline Kriteria & Persentase(\%) \\
\hline Sangat Layak & $81,26-100$ \\
\hline Layak & $62,51-81,25$ \\
\hline Cukup Layak & $43,76-62,50$ \\
\hline Tidak Layak & $25-43,75$ \\
\hline
\end{tabular}

Jurnal Tadris Kimiya 3, 2 (Desember 2018): 125-134

This is an open access article under CC-BY-SA license (https://creativecommons.org/licenses/by-sa/4.0/) 
Keterampilan kerja ilmiah mahasiswa yang dinilai mengggunakan rubrik penilaian dengan indikatornya ditunjukkan pada Tabel 5 .

Tabel 5. Indikator Keterampilan Kerja IImiah Mahasiswa

\begin{tabular}{|c|c|c|}
\hline No & Aspek Yang Diamati & Skor \\
\hline \multirow{4}{*}{1} & Kesiapan alat dan bahan & \\
\hline & $\begin{array}{l}\text { Menyiapkan semua alat dan bahan } \\
\text { yang diperlukan }\end{array}$ & 3 \\
\hline & $\begin{array}{l}\text { Membawa sebagian alat dan bahan } \\
\text { yang diperlukan }\end{array}$ & 2 \\
\hline & $\begin{array}{l}\text { Hanya membawa beberapa bahan } \\
\text { saja }\end{array}$ & 1 \\
\hline \multirow{4}{*}{2} & \multicolumn{2}{|l|}{ Kesiapan pribadi } \\
\hline & $\begin{array}{l}\text { Bekerja dengan tenang sesuai } \\
\text { panduan praktikum }\end{array}$ & 3 \\
\hline & $\begin{array}{l}\text { Bekerja dengan ragu-ragu namun } \\
\text { sesuai panduan praktikum }\end{array}$ & 2 \\
\hline & $\begin{array}{l}\text { Bekerja dengan ragu-ragu dan } \\
\text { bertanya kepada teman }\end{array}$ & 1 \\
\hline \multirow{4}{*}{3} & \multicolumn{2}{|l|}{ Penguasaan langkah kerja } \\
\hline & $\begin{array}{l}\text { Menguasai semua langkah kerja } \\
\text { dengan baik dan runtut }\end{array}$ & 3 \\
\hline & $\begin{array}{l}\text { Menguasai sebagian langkah kerja } \\
\text { dengan runtut }\end{array}$ & 2 \\
\hline & $\begin{array}{l}\text { Menguasai sebagian langkah kerja } \\
\text { namun tidak runtut }\end{array}$ & 1 \\
\hline \multirow{4}{*}{4} & \multicolumn{2}{|l|}{ Penggunaan alat } \\
\hline & $\begin{array}{l}\text { Mengetahui semua nama alat dan } \\
\text { fungsinya dengan baik }\end{array}$ & 3 \\
\hline & $\begin{array}{l}\text { Mengetahui sedikit nama alat dan } \\
\text { sedikit fungsinya }\end{array}$ & 2 \\
\hline & Hanya mengetahui nama alat & 1 \\
\hline & Menuliskan hasil pengamatan & \\
\hline \multirow{3}{*}{5} & $\begin{array}{l}\text { Menemukan hasil dan menuliskan } \\
\text { hasil pengamatan dengan jelas }\end{array}$ & 3 \\
\hline & $\begin{array}{l}\text { Menemukan hasil dan menuliskan } \\
\text { secara singkat saja }\end{array}$ & 2 \\
\hline & $\begin{array}{l}\text { Menemukan hasil namun kurang } \\
\text { tepat dalam penulisannya }\end{array}$ & 1 \\
\hline \multirow{4}{*}{6} & \multicolumn{2}{|l|}{ Membuat pembahasan } \\
\hline & $\begin{array}{l}\text { Membuat pembahasan sesuai hasil } \\
\text { pengamatan, lengkap dan benar }\end{array}$ & 3 \\
\hline & $\begin{array}{l}\text { Membuat pembahasan sesuai hasil } \\
\text { pengamatan, tidak lengkap, benar }\end{array}$ & 2 \\
\hline & $\begin{array}{l}\text { Membuat pembahasan namun salah, } \\
\text { tidak sesuai hasil pengamatan }\end{array}$ & 1 \\
\hline & \multicolumn{2}{|l|}{ Kemampuan membuat kesimpulan } \\
\hline \multirow{3}{*}{7} & $\begin{array}{l}\text { Membuat kesimpulan berdasarkan } \\
\text { tujuan percobaan dan benar }\end{array}$ & 3 \\
\hline & $\begin{array}{l}\text { Membuat kesimpulan berdasarkan } \\
\text { tujuan percobaan dan salah }\end{array}$ & 2 \\
\hline & Membuat kesimpulan tidak sesuai & 1 \\
\hline
\end{tabular}

\begin{tabular}{|c|c|c|}
\hline No & Aspek Yang Diamati & Skor \\
\hline & tujuan percobaan & \\
\hline \multirow{4}{*}{8} & \multicolumn{2}{|l|}{ Kebersihan alat dan bahan } \\
\hline & $\begin{array}{l}\text { Membersihkan dan mengembalikan } \\
\text { alat dan bahan sesuai tempatnya }\end{array}$ & 3 \\
\hline & $\begin{array}{l}\text { Hanya } \\
\text { membersihkan/mengembalikan alat } \\
\text { dan bahan saia }\end{array}$ & 2 \\
\hline & $\begin{array}{l}\text { Membiarkan alat dan bahan setelah } \\
\text { selesai praktikum }\end{array}$ & 1 \\
\hline \multirow{4}{*}{9} & \multicolumn{2}{|l|}{ Keberhasilan praktikum } \\
\hline & $\begin{array}{l}\text { Mahasiswa berhasil melakukan } \\
\text { praktikum dengan tepat, cepat, } \\
\text { benar dan mandiri }\end{array}$ & 3 \\
\hline & $\begin{array}{l}\text { Mahasiswa berhasil melakukan } \\
\text { praktikum dengan benar, tepat } \\
\text { namun lama }\end{array}$ & 2 \\
\hline & $\begin{array}{l}\text { Mahasiswa berhasil melakukan } \\
\text { praktikum dengan benar, lama dan } \\
\text { tidak mandiri }\end{array}$ & 1 \\
\hline
\end{tabular}

Skor mentah yang diperoleh diubah ke dalam bentuk persentase. Selanjutnya hasil persentase yang diperoleh dikonversi dalam kriteria keterampilan kerja ilmiah yang dimodifikasi dari Murdiani (2012) seperti dapat dilihat pada Tabel 6 .

\section{Tabel 6. Kriteria Observasi Keterampilan Kerja} IImiah

\begin{tabular}{|c|c|}
\hline Kriteria & Persentase (\%) \\
\hline Sangat Baik & $81,26-100$ \\
\hline Baik & $62,51-81,25$ \\
\hline Cukup & $43,76-62,50$ \\
\hline Tidak Baik & $25-43,75$ \\
\hline
\end{tabular}

\section{HASIL DAN PEMBAHASAN}

Pada tahap pendefinisian penelitian ini dilakukan analisis fasilitas dengan cara inventarisasi bahan dan alat yang terdapat pada laboratorium beserta kondisinya. Kemudian analisis terhadap materi kimia dasar dengan tujuan untuk acuan materi pokok pengembangan panduan praktikum kimia dasar. Hasil yang diperoleh pada tahap ini adalah terdapat 3 (tiga) topik praktikum yang dapat dikaitkan dengan lingkungan dan budaya lokal di Merauke, yang ditunjukkan pada Tabel 7. 
Tabel 7. Analisis Topik Praktikum yang Sesuai dengan Lingkungan dan Budaya Lokal Merauke

\begin{tabular}{|c|c|c|c|}
\hline No & Materi & Alat & $\begin{array}{c}\text { Bahan } \\
\text { lokal }\end{array}$ \\
\hline 1 & $\begin{array}{c}\text { Larutan } \\
\text { Elektrolit }\end{array}$ & $\begin{array}{c}\text { Lamp tester, } \\
\text { Beaker Glass, } \\
\text { Baterai }\end{array}$ & $\begin{array}{c}\text { Air } \\
\text { Sungai } \\
\text { Maro }\end{array}$ \\
\hline 2 & Laju Reaksi & $\begin{array}{c}\text { Beaker Glass, } \\
\text { Hotplate, Timer, } \\
\text { Termometer }\end{array}$ & $\begin{array}{c}\text { Sarang } \\
\text { Semut }\end{array}$ \\
\hline 3 & $\begin{array}{c}\text { Perubahan } \\
\text { Entalpi }\end{array}$ & $\begin{array}{c}\text { Beaker Glass, } \\
\text { Pipet Ukur, } \\
\text { Mortar }\end{array}$ & $\begin{array}{c}\text { Tepung } \\
\text { Sagu }\end{array}$ \\
\hline
\end{tabular}

Pada tahap perancangan dilakukan pengumpulan sumber atau referensi yang terkait dengan materi praktikum kimia yang berupa buku dan jurnal yang berikutnya pemilihan format untuk penulisan panduan praktikum kimia dasar.

Pada tahap desain panduan praktikum kimia dasar draf 1 (satu) sesuai dengan format penulisan yang dipilih, selanjutnya dikoreksi dan divalidasi oleh ahli materi dan media berdasarkan kekonsistenan dengan format penyusunan panduan praktikum kimia dasar. Perbaikan pada panduan praktikum kimia dasar yang menghasilkan draf 2 (dua) selanjutnya divalidasi oleh validator ahli materi meliputi kebenaran konsep materi praktikum. Selanjutnya validasi media oleh validator ahli media meliputi tampilan fisik dan kebahasaan. Dalam validasi media dilakukan perbaikan karena penulisannya masih ada yang yang kurang benar serta tampilan gambar yang kurang jelas. Setelah dilakukan perbaikan pada validasi media dihasilkan draf 3 (tiga). Panduan praktikum kimia dasar draf 3 (tiga) telah dinyatakan valid dan layak oleh validator ahli materi dan media. Hasil validasi ahli materi dan ahli media ditunjukkan pada Gambar 2.

Penilaian materi dilakukan untuk menentukan kesesuaian materi dan kebenaran konsep sesuai yang diajarkan. Penilaian kelayakan materi terdiri dari sepuluh butir yaitu kebenaran konsep dan tingkat keterlaksanaan praktikum. Validator memberikan penilaian berupa tanggapan positif untuk keseluruhan komponen. Saat validasi produk draf satu mendapatkan persentase $62,50 \%$ dengan kriteria cukup layak dan perbaikan pada tata tertib praktikum, penyajian materi yang masih belum runut, kesesuaian tema praktikum dengan tujuan, dasar teori, alat, bahan, cara kerja dan teknik analisis yang belum semua sesuai dengan materi praktikum yang akan dilakasanakan, ada beberapa penambahan alat praktikum dan perbaikan pada penyusunan prosedur kerja. Setelah direvisi, draf dua memperoleh persentase 65,00\% dengan kriteria layak. Walaupun dinyatakan layak namun validator materi memberikan masukan untuk perbaikan pada dasar teori untuk lebih terperinci, dan pembuatan diagram prosedur kerja serta format laporan praktikum untuk dilampirkan. Pada revisi draf dua memperoleh presentase $75,00 \%$ dan dinyatakan layak untuk digunakan dalam praktikum. Hasil penilaian atau hasil validasi yang mendapatkan persentase diatas $62,50 \%$ dapat dinyatakan layak digunakan dari sebuah produk pengembangan (Hermawati, 2016).

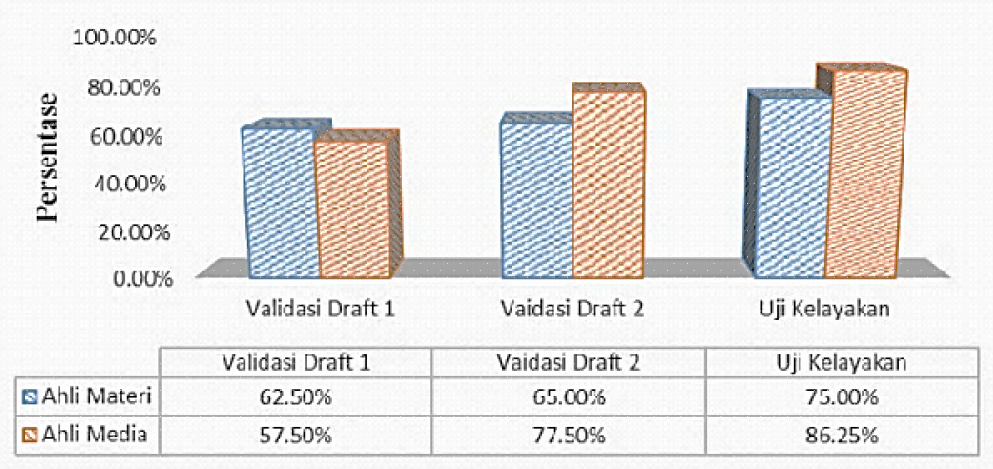

Gambar 2. Hasil Validasi dan Uji Kelayakan oleh Ahli 
Penilaian media meliputi tampilan fisik dan kebahasaan. Penilaian kelayakan media mengandung sepuluh butir penilaian yang jumlahnya sama dengan butir penilaian materi. Hasil penilaian draf satu untuk kelayakan tampilan panduan praktikum kimia dasar mendapatkan persentase sebesar $57,50 \%$ kriteria cukup layak dengan perbaikan pada tampilan fisik ilustrasi sampul yang belum menampilkan keserasiannya dengan judul buku praktikum. Ilustrasi pada sampul hendaknya menampilkan gambar-gambar kearifan lokal yang ada di Merauke yang sesuai dengan tema praktikum, ukuran huruf yang belum serasi, dan penyesuaian penyajian dengan format yang dipilih. Tampilan halaman sampul dapat dilihat pada Gambar 3.

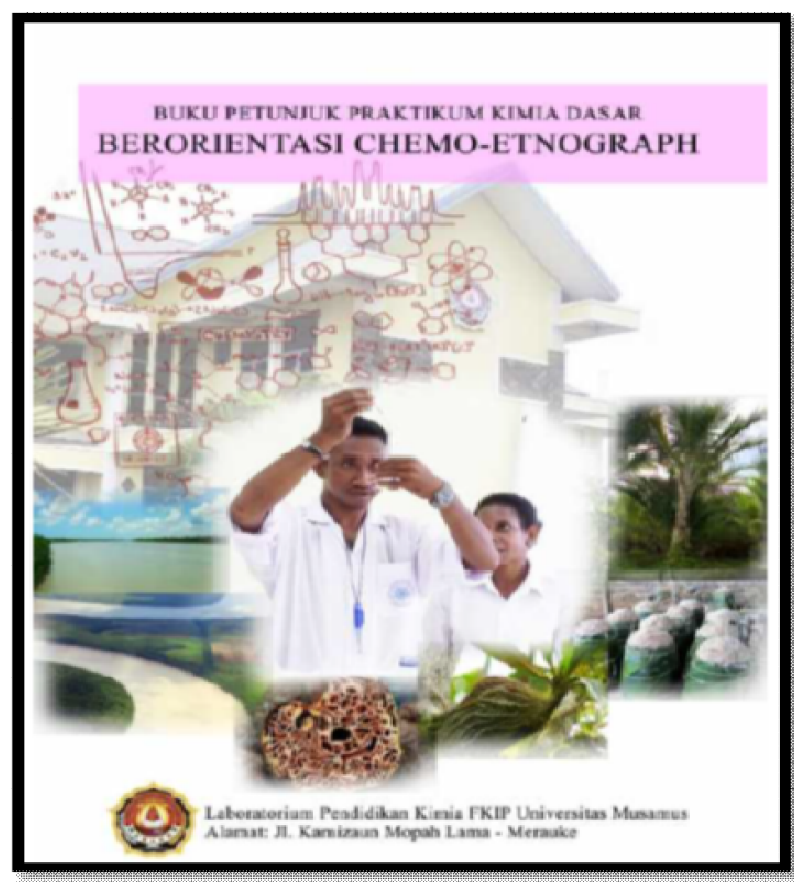

\section{Gambar 3. Halaman Sampul Panduan Praktikum Kimia Dasar}

Setelah dilakukan perbaikan, draf dua mendapatkan persentase $77,50 \%$. Walaupun dinyatakan layak namun validator media memberikan masukan untuk perbaikan penyempurnaan pada pemilihan kata dan ejaan yang perlu diperhatikan lagi karena masih ada beberapa penulisan yang belum benar. Setelah dilakukan perbaikan dinyatakan layak untuk digunakan dalam praktikum dengan hasil persentase penilaian $86,25 \%$.
Pengembangan Panduan Praktikum Kimia Dasar Terintegrasi Etnokimia untuk Mahasiswa

Panduan praktikum yang dikembangkan juga memuat komponen-komponen yang harus ada dalam sebuah petunjuk praktikum. Komponen dalam petunjuk praktikum harus memuat judul praktikum, tujuan praktikum, dasar teori, alat dan bahan, cara kerja, dan evaluasi. Petunjuk praktikum telah dilengkapi dengan tata cara keselamatan kerja untuk mengantisipasi kecelakaan kerja selama di laboratorium.

Pada Gambar 4 disajikan kutipan halaman percobaan laju reaksi menggunakan sarang semut dan pada Gambar 5 disajikan kutipan halaman percobaan $\Delta \mathrm{H}$ reaksi menggunakan sampel sagu. Petunjuk praktikum harus memuat aspek keselamatan dalam melaksakan kegiatan praktikum berupa peringatan yang dituliskan atau lambanglambang yang digunakan (Maharani, 2013).

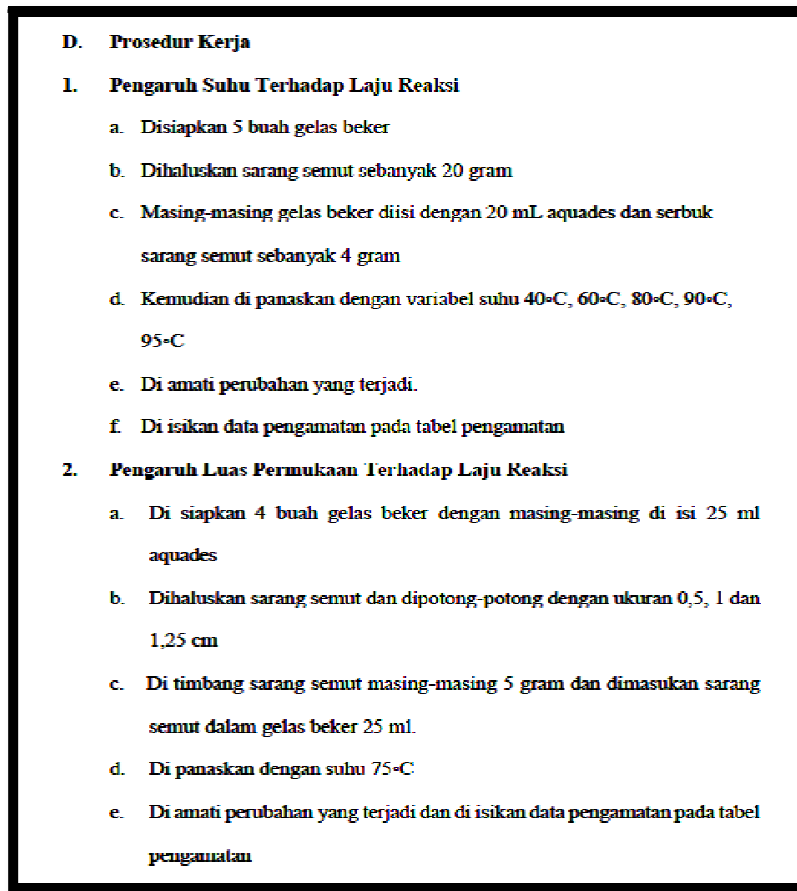

Gambar 4. Kutipan Halaman Percobaan Laju Reaksi menggunakan Sampel Sarang Semut 


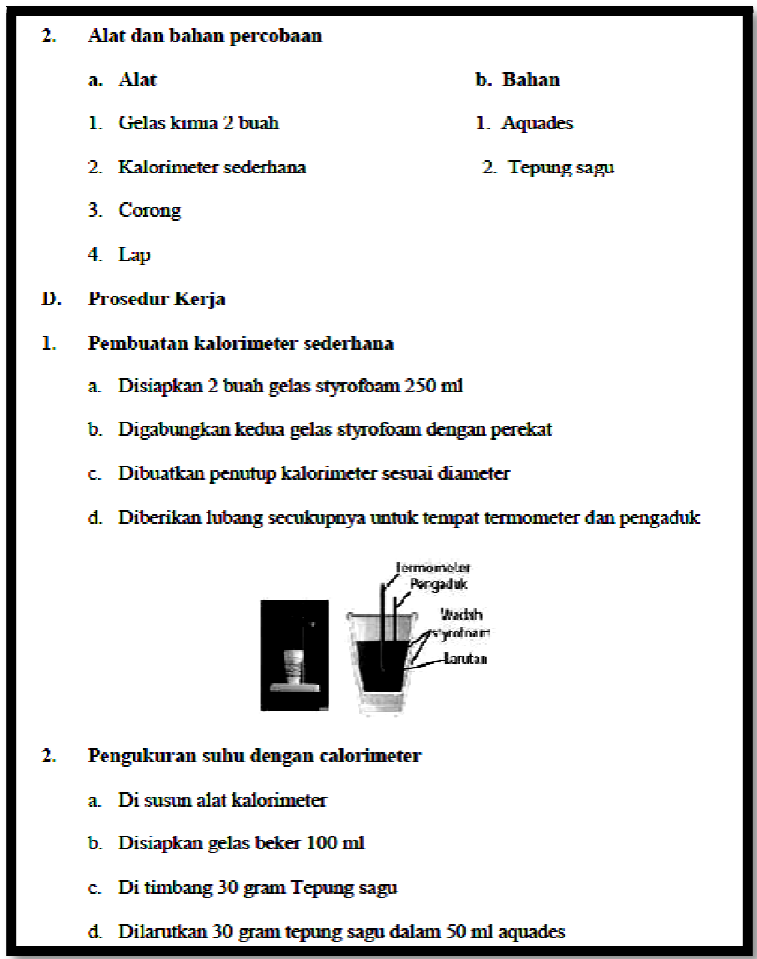

Gambar 5. Kutipan Halaman Percobaan $\Delta H$ Reaksi menggunakan Sampel Sagu
Pada tahap pengembangan dilakukan uji coba terbatas pada subjek penelitian. Instrumen angket respon mahasiswa dan observasi keterampilan kerja ilmiah terhadap panduan praktikum kimia dasar setelah dikonversi diperoleh hasil seperti ditunjukkan oleh Gambar 6.

Pelaksanaan praktikum untuk masing-masing topik berjalan dengan lancar. Angket respon mahasiswa dibagikan saat uji coba terbatas. Berdasarkan hasil pengisian angket respon, mahasiswa mampu memahami materi serta proses pelaksanaan praktikum sesuai dengan produk pengembangan panduan praktikum kimia dasar sehingga mendapatkan respon posistif untuk semua topik praktikum yang disusun. Perhitungan persentase respon mahasiswa pada topik praktikum larutan elektrolit, laju reaksi, dan perubahan entalpi secara berturut-turut adalah 85,70\%, 86,65\%, dan $86,40 \%$.

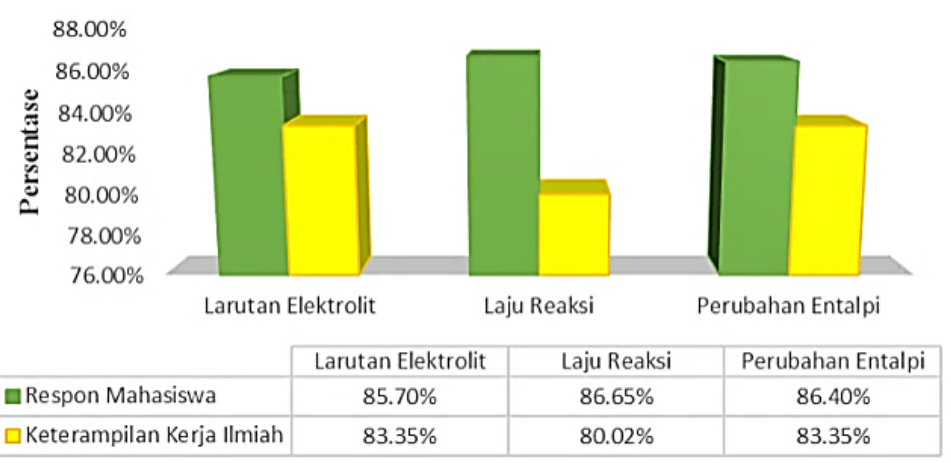

\section{Gambar 6. Hasil Uji Coba Terbatas}

Secara keseluruhan panduan praktikum kimia dasar mendapatkan skor rata-rata sebesar $86,25 \%$ yang artinya berada pada kriteria sangat layak. Petunjuk praktikum selain dirancang untuk memberi pemahaman kepada mahasiswa, juga diharapkan dapat membangun kompetensi dan kepercayaan diri mahasiswa, di mana percobaan yang dilakukan merupakan fondasi dari ilmu pengetahuan kimia supaya mahasiswa dapat memahami, menghargai dan mengaplikasikan konsep kimia tersebut (American Chemical Society, 2009).
Penilaian keterampilan kerja ilmiah mahasiswa menunjukkan hasil yang baik untuk keseluruhan indikator. Mahasiswa mampu memahami panduan praktikum sehingga dapat menyiapkan alat dan bahan sesuai panduan, menguasai langkah kerja, penggunaan alat, cara pengamatan serta pembuatan laporan praktikum. Pada penilaian keterampilan kerja ilmiah perhitungan skor topik praktikum larutan elektrolit, laju reaksi, dan perubahan entalpi secara berturut-turut adalah 83,35\%, 80,02\%, dan 83,35\%. Secara keseluruhan panduan praktikum kimia dasar 
mendapatkan skor rata-rata sebesar $82,24 \%$ yang artinya berada pada kriteria sangat baik. Hal ini sejalan dengan hasil penelitian Handayani dkk. (2014), yang menyatakan bahwa aktivitas siswa selama kegiatan praktikum dikategorikan tinggi dan hasil belajar ranah kognitif, afektif, dan psikomotor menunjukkan hasil yang baik setelah menggunakan penuntun praktikum. Dengan demikian untuk meningkatkan keterlibatan siswa secara aktif terhadap belajar dan berusaha menemukan konsep sendiri dalam proses pembelajaran adalah dengan kegiatan praktikum. Disarankan dilakukan penyempurnaan produk sebelum menjadi produk akhir untuk disebarluaskan.

\section{KESIMPULAN}

Hasil penelitian menunjukkan panduan praktikum kimia dasar terintegrasi etnokimia yang dikembangkan memperoleh persentase rata-rata uji kelayakan oleh ahli materi $75,00 \%$ dan oleh ahli media $86,25 \%$. Persentase ratarata respon mahasiswa pada saat uji coba terbatas diperoleh $86,25 \%$ pada kategori sangat layak, sehingga dapat disimpulkan bahwa produk pengembangan layak digunakan untuk proses pembelajaran. 


\section{DAFTAR PUSTAKA}

American Chemical Society. (2009). ACS Guidelines for Chemistry inTwo-Year College Programs: Spring 2009. Washington, DC: American Chemical Society.

BNSP. (2006). Standar Isi Untuk Satuan Pendidikan Dasar dan Menengah. Jakarta: Badan Standar Nasional Pendidikan.

Chang, R. (2005). Kimia Dasar: Konsep-konsep Inti (Jilid 1) (Edisi 3).Alih bahasa: Suminar Setiati Acmadi. Jakarta: Erlangga.

Darmanto. (2009). Local Genius sebagai Competitive Advantage Perguruan Tinggi, Makalah Lokakarya Local Genius. Wisma Joglo Yogyakarta 3-4 Februari 2009.

Handayani, L. P., Farida, F., \& Anhar, A. (2014). Pengembangan Buku Penuntun Praktikum IPA Berbasis Inkuiri Terbimbing untuk SMP Kelas VII Semester II.Kolaboratif, 1(3).

Hermawati. (2016). Pengembangan Modul Keanekaragaman Aves Sebagai Sumber Belajar Biologi. Jurnal Lentera Pendidikan LPPM UM METRO, 1, 28-36.

Maharani, M. U. (2013). Pengembangan Petunjuk Praktikum IPA Terpadu Tema Fotosintesis Berbasis Learning Cycle untuk Siswa SMP. Skripsi, Fakultas Matematika dan IImu Pengetahuan Alam: Universitas Negeri Malang.

Merdekawati. (2012). Menumbuhkan Keunggulan Bangsa Melalui Pendidikan Kimia Berbasis Local Genius. Prosiding Seminar Nasional Pendidikan Sains UNS, 3, 1-8. Surakarta.

Murdiani, I. (2012). Pembelajaran Biologi Menggunakan Metode E-learning Berbasis Multiple Intelligences pada Materi Sistem Gerak Manusia.
Innovative Journal of Curriculum and Educational Technology, 2, 5-6.

Murti, S., Muhibbuddin, \& Nurmaliah, C. (2014). Penerapan Pembelajaran Berbasis Pratikum Untuk Meningkatkan Kemampuan Kognitif dan Psikomotorik Pada Perkuliahan Anatomi Tumbuhan. Jurnal Biologi Edukasi, 6.

Prayitno, T. A. (2017). Pengembangan Petunjuk Praktikum Mikrobiologi Program Studi Pendidikan Biologi. Jurnal Biota Fakultas Pendidikan Ilmu Eksakta, 3, 3137.

Wimbarti, S. (2009). Integrasi Local Genius ke dalam Sistem Pembelajaran, Makalah Lokakarya Local Genius. Wisma Joglo Yogyakarta 3-4 Februari 2009.

\footnotetext{
This is an open access article under CC-BY-SA license (https://creativecommons.org/licenses/by-sa/4.0/)
} 